\title{
EL FUERO Y LAS «CONSTITUTIONES REGNI MURCIE» DE JAIME II DE ARAGON (1296-1301)
}

\author{
Juan Manuel del Estal \\ Universidad de Alicante
}

Bajo el presente epígrafe nos proponemos abordar el polémico tema del Nuevo Fuero de Murcia, desde su colación por Jaime II de Aragón, en 1296, hasta su reedición, corregida y aumentada, por el propio monarca aludido, el 1301.

La ocasión circunstancial de este trabajo ha sido el feliz hallazgo de un privilegio real de aquel soberano, con destino al procurador general del reino de Murcia, Bernat de Sarrià, y a todos sus baúles, justicias, alcaldes y demás oficiales y súbditos del mismo, fechado en Murcia, a 18 de febrero de 1301, por el que sancionaba formalmente las modificaciones, aclaraciones, supresiones, cambios y adiciones que, a instancia de los procuradores de la ciudad y reino de Murcia, se habían llevado a cabo por disposición regia sobre el fuero primitivo del 1296.

Modificaciones y cambios que tipifica explicitamente el monarca en los siguientes términos: "declarationes et additiones, correctiones, substractiones et mutationes in foris sive legibus specialibus dicti Regni, quos olim (1296) edidimus", y la que en la fecha apuntada les remite debidamente autenticadas con su sello secreto (1301). Modificaciones y adiciones nuevas, prosigue Jaime II en el protocolo inicial del citado documento, que ha incorporado al Fuero primitivo murciano, promulgado por él mismo cinco años antes (1296), y que habrán de ser tenidas en cuenta necesariamente en lo sucesivo, así dentro como fuera de los juicios. 
Se trata sencillamente de la promulgación oficial de un nuevo cuerpo de disposiciones reales, que, bajo el título de "Constitutiones Regni Murcie", añadía Jaime II al Fuero que un lustro antes había otorgado a la ciudad y reino de Murcia (25 de octubre 1296), a raíz de la conquista aragonesa de la capital murciana (19 mayo 1296).

Por cuanto queda bien patente a la vista de lo dicho, la existencia del citado fuero aragonés de Murcia, no admitido generalmente, como es bien sabido, por los historiadores de aquel reino. (Vid. supra, notas 12-16 y bibliografía respectiva).

Por todo ello dividimos el presente trabajo en los apartados siguientes:

I. Conquista y anexión del reino castellano de Murcia por Jaime I/ de Aragón.

II. Fuero Nuevo de Murcia otorgado por el monarca aragonés a raíz de la ocupación de aquella capital (19.V.1296).

III. Las Constitutiones Regni Murcie incorporadas por Jaime II al Fuero de Murcia en 1301, como apéndice complementario del mismo.

\section{Conclusiones finales:}

Completa este estudio, a modo de apéndice, un anexo documental, donde tendrá oportunidad el lector de compulsar los textos en toda su integridad, sirviendo todos ellos de contexto y marco histórico adecuado para una mejor inteligencia del Fuero Nuevo del reino de Murcia.

\section{CONQUISTA Y ANEXION DEL REINO DE MURCIA POR JAIME II A LA CORONA DE ARAGON.}

No pretendemos describir aquí en este apartado las visicitudes sucesivas por las que pasó el reino de Murcia, desde el momento inicial en que Jaime II de Aragón comenzó a ocupar sus plazas fuertes (22 de abril de 1296: castillo y villa de Alicante) hasta la capitulación definitiva y sometimiento final del castillo de Lorca (18.XII.1300 al 21.I.1301), último reducto castellano rebelde a la causa de Aragón (1). Tan sólo pretendemos subrayar la coincidencia temporal de la concesión por Jaime II de un Fuero Nuevo a la ciudad y reino de Murcia (octubre 1296) y la modificación y corrección del mismo, mediante la promulgación de las Constitutiones Regni 
Murcie (febrero 1301), por el mismo monarca aragonés, con el tiempo dedicado por este soberano a la conquista y entera sumisión del reino murciano (22 abril 1296 al 21 enero del 1301).

Circunstancia ésta de la entera pacificación del reino de Murcia y ya plena jurisdicción aragonesa soberana sobre el mismo, digna de tenerse en cuenta, al permitirle ahora a Jaime II dedicar ya mayor atención a los problemas de gobierno del mismo y a su mejor administración. Queremos a su vez anotar que todo ello se enmarca perfectamente en el contexto de rechazo y abierta oposición armada de las gentes del reino castellano de Murcia a la intervención militar aragonesa, muy lejos por cierto de aquel aserto gratuito de Francisco Cascales (2), cuando escribía a mediados del siglo XVIII, que Jaime II "teniendo rendidos todos los castillos importantes, villas y lugares, era recibido de todos con gran fiesta y reconocido por señor", no suponiendo más la sumisión del entero reino de Murcia, que "un autèntic passaig militar" (3), lo que dista mucho de ajustarse a la realidad de los hechos. Un solo dato demostrativo baste para refutar por insostenibles tales afirmaciones, prodigadas sin fundamento sólido hasta nuestros días: (4) la resistencia armada que le ofrecieron todas las ciudades, villas y lugares del citado reino, que no se avino en modo alguno a aceptar espontaneamente y sin lucha su soberanía, la que hubo de serle impuesta por la fuerza de las armas. Un caso tan solo hay de excepción a la regla susodicha, en el que de entrada no se rechazó la nueva hegemonía aragonesa, sino que más bien se acató a Jaime II como propio soberano, entregándole espontaneamente la plaza. Fue este único caso de excepción Crevillente, cuyo arráez, Muhammad ibn Hudayr, se declaró formalmente vasallo suyo (17 mayo 1296), haciendo colocar en prueba de ello el vexillo rea/ de Aragón sobre la torre más alta de su castillo (5). Todas las demás plazas del reino murciano se negaron a una a acatar a Jaime II de Aragón como a su nuevo soberano y señor, debiendo en consecuencia abordar su sometimiento por la acción de las armas. Sin pretender aquí detenernos en forma alguna en la exposición detallada de los hechos de la conquista aragonesa del reino de Murcia por Jaime II de Aragón, (remitiendo al lector deseoso de la relación pormenorizada de aquella acción guerrera a nuestro libro ya citado) (6) nos permitiremos consignar a continuación, en apretada síntesis, el calendario de sumisión de las ciudades, villas y demás lugares fuertes del reino de Murcia, por orden cronólogico de la fecha de su conquista o capitulación, quedando con ello sobradamente desmotrado que la referida conquista estuvo muy lejos de traducirse en puro y simple paseo militar del monarca aragones con sus huestes por aquellas tierras, sino que hubo de emplearse a fondo y duramente a la empresa de su conquista y entera sumisión, por espacio de casi cinco años (abril de 1296 a enero del 1301). 
He aquí el calendario de las conquistas más significativas del reino de Murcia por Jaime de Aragón:

Villa y castillo de Alicante. 22 abril 1296.

Guardamar. 27 abril 1296.

Almoradí. 30 abril 1296

Callosa de Segura y castillo. 8 mayo 1296.

Abanilla. 6 mayo 1296.

Orihuela. 11 mayo 1296.

Castillo de Orihuela. 21 junio 1296.

Molina, Hellín, Cieza, Ricote, Lorquí, Ceutí, Alguazas y Catral. 1-11-19 mayo 1296.

Crevillente y Señorío: Cox, Albatera, Aspe, Chinosa y Mónovar. 17-19 mayo 1296.

Murcia y Alcázar-Nássir. 19 mayo 1296.

Castillo Monteagudo -Murcia-. 1/2 julio 1296.

Mula, Librilla y Alcalá o Puebla de Mula. 2 junio 1296 y 1301.

Cartagena. 2 junio 1296.

Cartagena -Castillo-. 23 julio 1296.

Elche. 27 julio 1296.

Alhama de Segura. 1 junio 1298.

Lorca, Mula y Alcalá (castillo). 18.XII.1300 y 21.I.1301.

Donde queda ampliamente reflejada la más que espaciada acción militar de la conquista aragonesa del reino castellano de Murcia y por cierto en nada equiparable a un puro y sencillo paseo militar por el mismo.

La permanencia del reino de Murcia bajo la corona de Aragón no llegó, como es sabido, al decenio, durando tan sólo ocho años y medio, desde el 22 de abril del 1296, fecha de la conquista del castillo y villa de Alicante por Jaime II, hasta el 18 de octubre del 1304, día fijado por la Sentencia Arbitral de Torrellas (Soria, 8-10 agosto 1304) para la ejecución efectiva de la partición del reino murciano, allí estipulada (7).

En un Acuerdo conjunto de los monarcas Jaime II y Fernando IV, firmado en Tarazona, el 13 de agosto de 1304, se obligaban reciprocamente entrambos a la retrocesión de los lugares designados en la Sentencia Arbitral aludida, antes de la fiesta de San Lucas (18 octubre 1304) encomendando dicha tarea respectivamente Jaime II al comendador santiaguista de Montalbán, D. Artal de Huerta, y Fernando IV por su parte al maestre santiaguista también y comendador de Uclés, D. Juan de Osores (8). 
Discrepancias subsiguientes al fallo arbitral de Torrellas, por razón de límites territoriales imprecisos, en la vega baja del Segura, entre los reinos de Valencia y Murcia, suscitarían luego numerosos litigios, que no acabarían legalmente hasta mayo del año siguiente, con la firma de un nuevo pacto de fronteras, el conocido Acuerdo de Elche (19 de mayo de 1305), en el que delegados y expertos de una y otra corona pusieron punto final a esta controversia, fijando la precisa delimitación territorial del reino de Murcia, castellano de nuevo, y la recién nacida Procuración General de Orihuela o bien Reino de Valencia ultra Sexonam, desde Jijona, Aguas y Barranco de Aguas, en el término de Villajoyosa, hasta el confín comunal de Orihuela con el de Murcia, entre el Pilar de la Horadada y San Pedro del Pinatar, lugares hoy confinantes en el limite interprovincial actual de alicante y Murcia respectivamente $(9)$.

En este marco temporal del Reino de Murcia bajo Aragón (12961304/5), va a tener lugar la concesión de un Fuero a la ciudad y reino de Murcia por Jaime II de Aragón, el año 1296 y casi cinco años después, febrero 1301, la remodelación ulterior del mismo, con nuevos retoques y cambios considerables, por obra del mismo soberano.

Uno y otro capítulos son objeto del segundo y tercer apartado respectivamente que abordamos a continuación.

\section{NUEVO FUERO DE MURCIA PROMULGADO POR JAIME II DE ARAGON (1296).}

Jaime II no relegó en modo alguno a un segundo plano la obra legislativa de administración y gobierno del reino de Murcia, cuya conquista y ocupación acababa de acometer, en la primavera del año 1296.

A los tres meses escasos de iniciar la referida conquista, con la ocupación por la fuerza y sangriento combate del castillo y villa de Alicante (22 abril 1296), obtenía ya la obediencia y sumisión de casi la totalidad del reino castellano de Murcia, tras la capitulación de muy importantes plazas fuertes, como las de Orihuela y su castillo empinado (21 junio), castillo de Mula (2 junio del 1296, sin bien se sublevó luego hasta enero del 1301), castillo de Monteagudo (2 julio 1296), villa de Cartagena y castillo (23 julio) y la calahorra y villa de Elche (27 julio 1296), quedándole solamente por someter muy contadas plazas, como las de Lorca, Mula y Alcalá o Puebla de Mula, que no pasarían a su jurisdicción soberana hasta las primeras se- 
manas del 1301 (10). $Y$ al cabo de esos tres meses de progresiva instalación de la hegemonía aragonesa en tierras murcianas, comenzó ya Jaime II a interesarse por la normativa legal vigente en aquel reino, de sus estatutos de gobierno y fueros propios.

Es por ello tan significativa y reveladora al respecto la notificación que hace Jaime II al Justicia de Murcia, Pedro Jiménez de Espilonga, desde el sitio de Elche (3 julio 1296), que, mientras se compila el Fuero Nuevo, que ha otorgado a la ciudad y reino de Murcia, se sirvan del fuero que venían disfrutando hasta la fecha, concedido en su día por Alfonso X el Sabio, y que en aquellos casos donde no alcance tal fuero castellano a brindarles la solución deseada, que acudan al Fuero de Valencia, en busca de la resolución necesaria, hasta que les haga entrega del Nuevo Fuero de Murcia que ya se está compilando: "utamini foro Valentie donec dicta compilatio dicti fori Murcie facta fuerit" (11).

De cuyo elocuente testimonio se desprenden tres afirmaciones de máximo interés al respecto:

1. La existencia en Murcia de un fuero castellano propio, otorgado por Alfonso X el Sabio y vigente hasta la fecha (1296).

2. El recurso necesario al fuero de Valencia, en cuantos casos no se pronuncie el fuero alfonsino murciano.

3. La concesión por Jaime II de Aragón de un fuero nuevo a la ciudad y reino de Murcia, fuero que por orden real suya se está confeccionando ya entonces (3 julio 1296).

1. Aplicación del Fuero Real Alfonsí en Murcia.

La concesión del Fuero Juzgo y Real a la capital murciana por Alfonso $X$ el Sabio (14 mayo 1266), mediante la atribución del Fuero de Sevilla, es un hecho ampliamente documentado (12). Y las restricciones de aquél fueron compensadas con creces seguidamente por el mismo monarca con ulteriores privilegios, en confirmación de los ya existentes $o$ añadiendo otros nuevos, pero manteniendo siempre su vinculación a los fueros y privilegios de Sevilla, como aparece claramente atestiguado a lo largo de la baja Edad Media (13). 
Ello no obsta, sin embargo, para que el Rey Sabio, a tenor de las investigaciones más recientes (14), aplicara también en la ciudad de Murcia el Fuero Real, recientemente compilado entre otros por su colaborador, Jacobo de las Leyes, colector de las rentas reales, juez y repartidor mayor en la capital del Segura (1255). Si bien, escribe otro insigne estudioso de la legislación alfonsina, "Las cuestiones sobre Fuero Real están en estos momentos en estudio y todavía no conocemos con precisión el sentido del Fuero Real, pero podría tratarse de una adaptación del Fuero Juzgo a zonas que tenían derechos de frontera, para asegurar mayor presencia del rey y sus delegados, con una mayor intervención, que asegurase mejores ingresos" (15).

De todas formas, la aplicación de un fuero castellano en la ciudad y reino de Murcia, y en vigor por obra de Alfonso $X$ el Sabio, e identificable con el Fuero Real alfonsí, se ofrece hoy al historiador como la tesis más aceptable y de fácil comprobación documental (16).

El propio Jaime II de Aragón, apenas transcurrido mes y medio de la conquista de Murcia y su palacio intraurbano del Alcázar-Nássir (19.V.1296), hacía expedir una carta al justicia municipal de aquella ciudad, Pedro Jiménez de Spilonga (3 julio 1296), en la que le notificaba que, mientras se compilaba el fuero que acababa de otorgar a la ciudad de Murcia, continúe aplicando el Fuero del rey de Castilla, Alfonso X el Sabio, como vinieron haciendo hasta la fecha: "Mandamus et dicimus vobis donec compilatio que fieri debet de foro Murcie, per nos universitati Murcie concesso, utamini foro que utebamini tempore illustris dompni Alfonsi quondam regis Castelle, predecessoris nostri in Regno Murcie supradicto" (17). Fuero aquél castellano que pudiera ser muy bien el antes referido Fuero Real.

Y con idéntica fecha ordenaba imperante el monarca aragonés a dos notables jurisperitos murcianos, Martín de Dios y Juan de Meeya o Meeyani, que procediesen cauta y diligentemente a la compilación del Nuevo Fuero de Murcia, con la celeridad mayor posible: "...mandamus et dicimus vobis quod in compilatione per vos facienda de Foro per Nos concesso probis hominibus et universitati civitatis Murcie, caute et diligentissime prout celerius poteritis procedatis" (18). Y que deberían tenerlo ultimado y concluido integramente muy en breve, de suerte que en su próximo viaje a la capital del Segura, a principios de agosto, pudiera ya supervisarlo personalmente y hacer en él las modificaciones o retoques que juzgara oportunos: "Taliter faciendo quod cum Nos ad dictam civitatem accesserimus dicta recapitulatio sit perfecta et Nos super ea facere quod facere haberemus" (19). 
De donde se desprende claramente que la ciudad de Murcia seguía disfrutando, varias semanas después de su ocupación aragonesa, de un fuero castellano, que le diera Alfonso el Sabio, presumiblemente el Fuero Real en cuatro libros, antes mencionado. Y que además Jaime II autorizaba al consell murciano a proseguir sirviéndose del citado fuero alfonsí, hasta que les entregase el Nuevo Fuero, que ya se estaba compilando por los dos maestros en leyes, ya conocidos, Martín de Dios y Juan de Meeya, y el jurista y canónigo leridano, Raymundus Caprarii o Ramón Cabré o de Cabrera (20).

Testimonio más que elocuente del singular y admirable respeto del monarca de Aragón a la normativa legal castellana allí vigente hasta la fecha, imponiendo al común murciano seguir ateniéndose en sus juicios al dictamen de aquel viejo fuero de Castilla, hasta que dispusiesen de otro nuevo, cuya compilación se estaba llevando ya a cabo por orden suya real con patente apremio. La respuesta de Jaime II al consell murciano en confirmación de sus fueros y privilegios castellanos precedentes es sumamente reveladora al respecto (21).

\section{Recurso obligado al Fuero de Valencia en los casos que no contemple el Fuero Alfonsi murciano.}

Tras respetar Jaime II de Aragón la vigencia de las instituciones castellanas en el reino de Murcia, que estaba sometiendo (abril-julio 1296), en tanto que se compilaba el Nuevo Fuero de Murcia (22), ordenó al concejo murciano y muy en particular a su justicia, Pedro Jiménez de Spilonga, que en cuantos casos no se encuentre respuesta adecuada en el Fuero Alfonsí aludido, recurra al Fuero de Valencia, donde hallará de seguro la resolución deseada del caso en cuestión (23).

El monarca aragonés es tajante a este propósito: "et in eo in quo dictus forus (dompni Alfonsi quondam regis castelle) non sufficeret, utamini Foro Valentie donec dicta compilatio dicti Fori Murcie (cuya compilación tiene ya encomendada por aquellas fechas a tres expertos jurisconsultos) facta fuerit ut est dictum" (24).

Jaime II tiene muy claro que el Fuero otorgado por su abuelo, Jaime el Conquistador, a la ciudad y reino de Valencia es óptimo y muy completo y por ello no duda en imponer el recurso al mismo en los casos expresados por una razón más que convicente: "quia forus Valentie est satis forus acceptabilis et sufficiens" (25). 
Por esta misma razón no dudaría un ápice algunos años después, en la primera mitad del 1308, cuando se redactaba en la cancillería real la Constitución o Carta Magna de las villas de Orihuela, Alicante, Elche y Guardamar (26), en imponer a sus respectivos consells la aceptación del fuero de Valencia como fuero propio municipal, si bien, añadiendo la salvedad jurídica de que el fuero valenciano no podría contravenir jamás los fueros locales propios, que habrían de quedar siempre a salvo en su vigor permanente. Jaime II es muy explícito al respecto: "placeret nobis quod vos (consell de Orihuela) et alie universitates (consells de Alicante, Elche y Guardamar) terre nostre ultra Sexonam forum ipsum Valentie haberetis, privilegiis vestris salvis" (27).

El monarca aragonés quiere imponer el fuero de Valencia a todas las comunidades de aquel reino, incluidas las situadas al sur de Jijona (ultra Sexonam), las que por estas fechas del 1308 configuraban la Procuración General de Orihuela, pero, eso sí, manteniendo siempre a salvo y vigentes sus fueros locales propios, de origen castellano unos, y otros, los más recientes, de la corona de Aragón (28).

Los furs valencianos van a servir como de cedazo idóneo, sobre el que habrán de insertarse los fueros todos del reino de Murcia bajo dominación aragonesa (1296-1304).

\section{Concesión de un Fuero Nuevo por Jaime // de Aragón al reino de Murcia.}

Como apuntábamos ya anteriormente (29), apenas iniciada por Jaime II de Aragón la conquista y anexión del reino castellano de Murcia a su corona, se ocupó también de dotarlo de una normativa legal nueva, correspondiente a su nuevo status político.

Con este fin se dirigía ya el monarca, desde el sitio a la villa de Elche, a principios de julio del 1296, a sus dos eminentes jurisperitos murcianos, Martín de Dios y Juan de Meeya o Meeyani, para encomendarles la compilación del nuevo fuero de la ciudad y reino de Murcia, obra que habrían de llevar a feliz término, con la diligencia y cautela máximas, a la brevedad mayor posible: "caute et diligentissime prout celerius poteritis procedatis" (30).

Y añadía de seguido la razón de tal premura temporal: que esperaba ver un anticipo al menos del trabajo encomendado, sino plenamente concluido, sí muy adelantado, para poder revisarlo personalmente y modificar 
lo que estimase oportuno, en su próximo viaje a la ciudad de Murcia, adonde llegó en efecto a finales de aquel mismo mes, permaneciendo en aquella capital, desde el 30 de julio al 4 de agosto del 1296 (31).

Y por idéntica fecha debió encargar también la compilación del citado fuero de Murcia, al experto jurisconsulto y canónigo leridano, Ramón $\mathrm{Ca}$ bré o de Cabrera (Caprarii), para que colaborase activamente con los dos legistas murcianos, ya conocidos (32).

Durante la estancia del monarca aragonés en la ciudad de Murcia hizo llegar el consell municipal a su presencia la petición formal de que tuviese a bien confirmarles los fueros y privilegios castellanos de los que venían disfrutando desde Alfonso $X$ el Sabio hasta la fecha. Petición a la que asintió complacido Jaime II afirmativamente (33).

La susodicha confirmación real nos ha llegado en una copia notarial, efectuada por Domingo Soler, notario público de la ciudad de Murcia, algunas semanas después, con fecha del 29 de agosto del 1296 (34).

Por aquellas mismas fechas tenía ya el rey aragonés encomendada la compilación del Nuevo Fuero de Murcia a los tres jurisperitos ya apuntados y con el mandato expreso de concluirla a la brevedad mayor posible (35).

$Y$ en verdad que los juristas elegidos pusieron manos a la obra con la diligencia máxima exigida por el monarca, ya que apenas transcurridos tres meses y medio (36), procedía Jaime II al envío del Nuevo Fuero de Murcia al procurador general de este reino, Jaime Pérez, señor de Segorbe, con el mandato expreso de convocar en la capital del mismo a dos procuradores de cada uno de los lugares y villas del reino, al objeto de proceder en su presencia a la apertura y promulgación del Nuevo Fuero de Murcia: "Cum Nos Foros Murcie...sub uno volumine...ad civitatem Murcie transmittamus, sub sigilli nostri munimine interclusos, volumus ac vobis firmiter et expresse precipimus et mandamus quatenus visis presentibus, omni mora postposita et remota, ad civitatem Murcie vos personaliter transferretis, electuris ad hoc duobus probis uniuscuiuque loci nostri regni predicti hominibus, qui publico consilio faciatis volumen predictum aperiri ac etiam publicari" (37).

El Nuevo Fuero de Murcia se presentaba en un volumen, dividido en cuatro libros, al igual que el antiguo Fuero Real murciano, otorgado por Alfonso $X$ el Sabio, pero a diferencia de aquél, éste se hallaba redactado en catalán-valenciano. Estimamos conveniente hacer esta precisión, porque, 
aunque no se conozca el texto primitivo, pese a las numerosas copias que se hicieron del mismo por disposición real (38), hemos encontrado afortunadamente una segunda edición del mismo, corregida y aumentada por el propio monarca, apenas cinco años después (1301), en la que se retoca y corrige la edición primitiva, reproduciendo el incipit del párrafo en cuestión de aquélla, para brindarnos seguidamente la nueva redacción oficial, la que ha de quedar en vigencia plena sucesivamente. $Y$ tanto el incipit referido como su rectificación o remodelación aparecen redactados en romance valenciano, como podrá comprobar facilmente el lector en la transcripción que ofrecemos del citado hallazgo en el adjunto anexo documental (39).

Aunque el texto primitivo de este Nuevo Fuero de Murcia nos sea desconocido en su integridad, pese al mandato regio de hacer copiar dichos fueros en buena y clara letra y en excelente pergamino para dejar constancia manuscrita de los mismos en los diversos lugares y villas del reino (40), podemos acercarnos a su contenido sustancial a través de las Constitutiones Regni Murcie, que, como queda dicho, tuvimos la suerte de encontrar entre los registros de cancillería del citado monarca, y donde se nos lo reproduce parcialmente. Como tendremos ocasión de comprobar en el siguiente apartado, contra la opinión de preclaros historiadores del derecho institucional (41), Jaime II concedió un fuero propio al reino de Murcia, al medio año apenas de iniciar su conquista y ocupación, en octubre del 1296, imponiendo su vigencia plena y de modo excluyente en todos los lugares del reino, con términos bien precisos: "Quod nullus in civitate et regni Murcie locis in judicio vel extra amodo audeat aliis foris uti" (42).

Promulgaba así el monarca aragonés el citado Nuevo Fuero de la ciudad y reino de Murcia, quedando en lo sucesivo, desde el 25 de octubre del año 1296, como la suprema normativa institucional vigente en exclusiva en todos los lugares y villas del mismo.

$Y$ así permaneció inalterable su vigencia hasta que fuera retocado por el propio monarca, con fecha del 18 de febrero del 1301, cuyo estudio y publicación abordamos seguidamente.

\section{LAS CONSTITUTIONES REGNI MURCIE DEL a. 1301.}

La reiterada concesión de sucesivos privilegios forales por Jaime II de Aragón a la capital y demás lugares y villas del reino de Murcia, obligó a dicho monarca, a la vuelta de apenas cinco años, a una revisión inaplaza- 
ble y complementación del Nuevo Fuero de Murcia, alterado ya sustancialmente el contenido de muchos de sus párrafos.

En el transcurso de los años referidos otorgó Jaime II a los diversos concejos de aquel reino un sinfin de favores, gracias y mercedes, aparte de otras muchas disposiciones pecuniarias, fiscales o tributarias y de atención a los derechos igualitarios de mudéjares y judíos con el resto de la población cristiana de dicho reino murciano, que podrá constatar facilmente el lector con solo repasar el casi centenar y medio de documentos, correspondientes al marco temporal referido (25 octubre 1296 al 18 febrero de 1301) y publicados en el ya citado Corpus documental de el reino de Murcia bajo Aragón (43).

Tal era el cúmulo de cambios, correcciones, sustituciones, adiciones y añadidos registrados a lo largo del quinquenio referido en el Nuevo Fuero de Murcia, que Jaime II se vio obligado a atender la demanda de los concejos de la capital y demás lugares y villas del reino, que de forma unánime le suplicaban la revisión de dicho fuero (44).

El monarca, deseoso de complacer a sus súbditos, acabó accediendo gustoso a tal petición y con fecha del 18 de febrero del año 1301 hizo expedir a su cancillería la suma de cambios, correcciones, adiciones y omisiones, solicitadas, bajo el título de Constitutiones Regni Murcie, que en lo sucesivo deberían servir de complemento foral añadido al Nuevo Fuero de Murcia del 1296. Jaime II es muy explícito a este proposito al procurador general del reino de Murcia, Jaime Pérez, y a los bailes, justicias, alcaldes y demás oficiales públicos del mismo, ordenándoles añadir estas nuevas disposiciones reales suyas al volumen primitivo del fuero murciano y que hagan uso de él judicial y extrajudicialmente, cada vez que un caso concreto lo demande: "Quodcirca vobis et cuilibet vestrum dicimus et mandamus quatenus dictis declarationibus, correctionibus, substractionibus et mutationibus sicut inferius continetur, prout casus emerserint utamini in judiciis et extra, ipsasque in volumine fororum predictorum (fuero del 1296) seu legum adiciendo, observetis ac faciatis ab omnibus inviolabiliter obserari" (45).

El monarca aragonés accedió a la petición del consell de Murcia y demás concejos del reino, satisfaciendo los cambios, omisiones y añadidos propuestos por los mismos en los casos concretos presentados, pero eso sí como un apéndice tan solo del Fuero Nuevo de Murcia, que seguía manteniendo su plena vigencia legal, salvo en los casos que expresamente apunta a continuación, bajo este epígrafe: "Declarationes, additiones, 
correctiones, substractiones et mutationes predicte sunt hec que sequuntur" (46).

Y a continuación pasa el monarca a detallar los cambios introducidos en dicho fuero, reproduciendo primeramente el incipit de la rúbrica, o párrafo que ha sido objeto de cambio o corrección en el fuero de Murcia, senalando los términos primitivos y luego los nuevos con que ha de quedar enunciado definitivamente el párrafo aludido. Un ejemplo ilustrará mejor lo apuntado. Acerca de las competencias judiciales de la curia municipal, a la que el Fuero Nuevo de Murcia sometía todos los pleitos criminales y civiles del lugar, ahora delimita el monarca sus competencias, sustrayéndoles los crímines de herejía y lesa majestad y cuantos comporten la confiscación de bienes de la corona, por afectar a los derechos de regalía del señor rey. Leemos textualmente: "En la Rúbrica de la Cort en la ley que comença: $=\mathrm{La}$ Cort en sa pròpria persona en la casa etc. = là on diu = que oja e termén, pledeig e defenesca ab consell dels assessors e tots los clams qui seran en la ciutat e en tot lo terme etc, declara lo Senyor Rey que...lo Procurador General del Regne per son offici o altre official del senyor Rey o persona a qui lo senyor Rey o comanàs, poden demanar e punir per sí e sens la cort o la justicia de la ciutat o qual.ques.vol loc, crims e heretgía e de lesa magestat...e encara altres crims que emportassen per sa natura demanda o confiscació de béns del senyor Rey o a lurs familiars domèstics, com estes coses sien regalies del senyor Rey" (47).

La pauta antes aludida aparece plasmada bien claramente.

Otro ejemplo ilustrará todavía mejor el procedimiento seguido por el monarca en los cambios que introdujo en el Fuero Nuevo de Murcia, cinco años después de su promulgación, el año 1301.

Con referencia a la Rúbrica concerniente a la contestación de los pleitos sobre el último litigio, rectifica Jaime II el momento en que hayan de tener lugar las excepciones peremptorias, que ya no podrán hacerse dentro de los diez días inmediatos, después de conocerse la demanda, sino en los diez días sucesivos a haber sido contestado o recurrido el litigio. Dice textualmente la nueva Rúbrica acuñada: "Item en la Rúbrica de contestació de plets sobre la derrera lig, on diu que = totes excepcions peremptòries sien posades dins deu dies despuis la demanda serà conescuda, etc. $=\mathrm{E}$ declara lo senyor Rey que tota excepció peremptòria sia posada dins $X$ dies contínuus, útils o no útils aprés de la lit contestada e puys neguna", salvo la ignorancia de la misma, demostrada con juramento. Favoreciendo así con esta modificación de la Rúbrica primitiva la condición del reo. 
Y por último, un tercer caso de rectificación de otra disposición legal del Fuero Nuevo de Murcia. En la Rúbrica primitiva del Nuevo Fuero de Murcia, referente a los malhechores, se legislaba que todo caballero que desafiare a otro, habría de esperar en un plazo de diez días la respuesta del caballero desafiado para inferirle algún daño o perjuicio y que de no guardar el plazo prescrito sería considerado un traidor. $Y$ ahora añade el monarca a los bienes raíces del caballero desafiado, que podría dañar el desafiador, algunos más de nueva entidad y muy importantes por cierto, como la ocupación violenta de casa, torre, castillo o villa del ciudadano víctima de tal desafío, antes de haber transcurrido el plazo de los diez días fijados, por todo lo cual el caballero desafiante habrá de ser tenido por un traidor y obligado a resarcir con creces los daños causados y sufrir las penas en que haya incurrido.

Reza así el texto literal de la presente modificación: "Item en Rúbrica de malfeytors, en la ley que comença: =si alcú cavaller desafiarà altre cavaller, etc. $=$ là on diu: =e si.l matarà acordadament o nafrarà o ferrà ab nafra o sens nafra o li pendrà Vila o Castell o Torre o Casa o la derrocarà o la cremarà sens desafiament, que en aquests cases sia traydor" (49). Y concluye el monarca de seguido, que en el caso de aceptar la víctima el desafío lanzado, que el rey o su procurador general o justicia u otros oficiales del reino garanticen la seguridad de las partes en la ejecución de tal desafío (50).

La simple revisión de los tres casos ofrecidos a modo de ejemplo puede bastar de por sí para darnos idea de la pauta seguida por Jaime II en la redacción de las Constitutiones Regni Murcie, que concediera a este reino el año 1301, como apéndice complementario del Fuero de 1296. Un breve análisis textual del citado Fuero Nuevo de Murcia, a través de la revisión, modificación y demás declaraciones pertinentes, que hiciera del mismo el propio monarca en las Constitutiones referidas del 1301, nos permite subrayar ciertas conclusiones del presente estudio a modo de colofón final.

\section{CONCLUSIONES}

1. $\left.{ }^{a}\right)$ El Fuero Nuevo de Murcia se inspiró sustancialmente en el Llibre dels Furs valencianos, en un porcentaje altísimo, no difícil de precisar, a juzgar simplemente por las Rúbricas retocadas por Jaime II en la revisión que hiciera del mismo en 1301, bajo la ya conocida denominación de Constitutiones Regni Murcie. 
Nos vamos a limitar a cinco casos concretos en los que veremos confirmado ampliamente cuanto queda dicho.

a) Competencias de la Cort o curia municipal.

Los términos del correspondiente texto del Fuero de Murcia, que en la revisión del 1301 se quieren modificar, coinciden literalmente en casi su totalidad con los de Els Furs, en su Rúbrica De la Cort e del Batle, donde leemos: "La Cort en sa propria persona en la casa (51) que ça en rere era sepultura del Reys Serrayns, sigue, oje, termen, pledeig e defenesque ab consell dels prohomens de la Ciutat (de Valencia) o daltre loch del regne de Valencia on sia la Cort (52), tots los pleyts criminals e civils e tots los clams que seren en la Ciutat e en tot lo terme de la Ciutat" (53).

Donde las diferencias máximas que hallamos es la omisión de la referencia a la casa-panteón de los reyes sarracenos en Valencia, que se sustituye en el Fuero murciano por un etc. y la sustitución de las palabras que transcribimos algo antes sin subrayar, desde "prohomens" hasta "on sia la Cort" por estas del Nuevo Fuero: "ab consell dels assessors e tots los clams que seran en la ciutat (de Murcia y demás villas y lugares del reino) e en tot lo terme, etc" (54). Lo que nos autoriza a concluir que la interdependencia del Fuero murciano del Llibre dels Furs valencianos fue sustancial y máxima.

b) Sobre Pactos y Conspiraciones.

En este asunto también los Furs valencianos suministran al Fuero Nuevo de Murcia la base fundamental de su legislación, al reproducir éste (55) la Rúbrica idéntica de los Furs: "Sil crehedor retra al deutor la carta del deute" (56), siendo el texto el mismo en uno y otro fuero literalmente.

La diferencia única existente en el Fuero Nuevo es la gracia que otorga Jaime Il a la parte más débil del pacto, el deudor, extendiendo a favor de éste la presunción de haberle sido cancelada la deuda por el acreedor. Reza así el texto añadido por el monarca en la revisión efectuada del fuero murciano el 1301: "enedeix e ajusta lo senyor Rey aquestes paraules: =e és presumpció esser retuda la carta al deutor per lo acreedor, si aquella carta serà trobada tayllada en poder del deutor" (57). 
c) De los Testamentos.

También en este importante apartado sobre el derecho a testar y alcance jurídico de los testamentos, el Nuevo Fuero de Murcia depende sustancialmente del libro de los Furs valencianos.

Comienza por reproducir literalmente la Rúbrica foral valenciana (58) para añadir en la revisión apuntada del 1301, nuevos retoques de mayor favor para las partes, como se desprende de cuanto sigue: "Là on son aquestes paraules dels Furs: =Partesquen e donen=, corregeix lo senyor Rey que en loch d'aquelles paraules sien aquestes paraules:= pus quen partir e donar=: $E$ après aquelles paraules qui dien en la dita ley: =eguals $e$ no eguales $=$, que sien ajustades aquestes paraules: $=0$ altres persones a qui.s volran" (59).

\section{d) De Apelaciones.}

De igual modo que en las precedentes Rúbricas reproduce así el Fuero Nuevo de Murcia la Rúbrica de los Furs valencianos, que reza como sigue: "Tos los pleyts e les demandes que per la segona appellacio denant la nostra real presencia venran, etc" (60). y añade a continuación: "là on diu: =Mas en les segones apellaciones sien tenguts d'apellar e de venir a nós les parts e no davant altre, etc. $=(61)$, ampliando seguidamente la facultad de apelar en segunda instancia al monarca, si se hallare presente en el reino de Murcia, y en su ausencia se puede apelar al procurador general del mismo, lo que constituye un auténtico favor foral, que expresa en los siguientes términos: "Atorga lo Senyor Rey e declara la dita ley en aquesta manera:Que mentre ell sie en la ciutat o el Regne de Murcia que les segones apellacions venguen en tot cas a ell e a sa cort. Mas si el senyor Rey serà fora lo Regne de Múrcia o haurà Procurador General en lo dit Regne, son loctinent general que sia en volontat d'aquell qui se apellarà de apellar-se e d'anar al senyor Rey là on sia o al dit procurador e a son loctinent general qual més vula" (62).

El Fuero Nuevo de Murcia reproducía sin alteración alguna la Rúbrica de los Furs valencianos, reservando la apelación en segunda instancia en exclusiva al monarca y a nadie más, mientras que la revisión de aquél en 1301 amplía la facultad de la segunda apelación, autorizando a los súbditos del reino de Murcia a apelar, estando el monarca fuera del mismo, a su lugarteniente, el procurador general del reino de Murcia. 


\section{e) De los Malhechores y del Guerrear.}

También en lo concerniente al desafío lanzado por un caballero a otro caballero o ciudadano honrado, legislaba el Fuero Nuevo de Murcia con idénticos términos de los Furs valencianos: "Si alcun cavaller desafiara altre cavaller o honrat hom de la ciutat o de vila del regne de Valencia que non faça mester de ses mans que dintre deu dies non li faça mal pus laura desafiat. E si lo fahia dins deu dies que sia traydor". Y Jaime II amplió en la revisión del Fuero murciano, del 1301, los bienes inmuebles del ciudadano desafiado a los que podía dañar el desafiante como una casa, torre, castillo o villa de su propiedad (64), por cuya ocupación ilegítima y violenta sería tenido el caballero desafiante como un malhechor y un traidor.

De donde resulta que el Nuevo Fuero de Murcia del 1296 reproducía literalmente la Rúbrica citada de los Furs valencianos, modificándola solamente más tarde, en la revisión del 1301, con la ampliación apuntada.

A través de los cinco ejemplos referidos esperamos haber dejado ampliamente demostrada la inspiración sustancial del Nuevo Fuero de Murcia en el Llibre dels Furs valencianos, como 1. a conclusión.

2. $\left.{ }^{a}\right)$ Existencia de un Fuero Nuevo en el reino de Murcia promulgado por Jaime II de Aragón en 1296 y revisado y retocado algo después por él mismo en febrero de 1301. Vid. supra, notas 30-48 con el correspondiente texto respectivo.

3. $\left.{ }^{a}\right)$ Vigencia del Fuero Real de Alfonso $X$ el Sabio en el reino de Murcia, durante la hegemonía castellana hasta el año 1296. Vid. supra, notas 13-20 con sus correspondientes textos respectivos.

4. a) Reedición y revisión del Fuero Nuevo de Murcia el 1301 por Jaime II de Aragón bajo la denominación de Constitutiones Regni Murcie, que estuvieron en vigor en el reino murciano hasta su retrocesión a Castilla, desde el bajo Segura hasta su límite con el reino de Granada, por la Sentencia Arbitral de Torrellas del 1304. Vid. supra, notas 41-48 y textos respectivos correspondientes. 
5.a) Vigencia del Nuevo Fuero de Murcia del 1296 en la Procuración General de Orihuela o reino de Valencia ultra Sexonam hasta junio del año 1308, fecha de la concesión por Jaime II de un Fuero propio municipal a las villas de Orihuela, Alicante, Elche y Guardamar. Vid. supra, notas 24-26 con sus textos respectivos y Anexo, n. 7 . Esta nueva Constitución Foral o Carta Magna local pasó a sustituir el Fuero Nuevo de Murcia, hasta la fecha vigente en aquella región alicantina, que, por su incorporación formal al reino de Valencia (Vid. supra, notas 25-27 y textos correspondientes) entró dentro del marco jurídico del los Furs valencianos, pero, eso sí, disfrutando de un fuero propio local, promulgado por Jaime II a mediados del 1308. (Ibid.). 


\section{ANEXO DOCUMENTAL}

1296, agosto, 29. Murcia.

Traslado notarial de Domingo de Soler, notario murciano, de una carta de Jaime II de Aragón, dirigida al consell de Murcia (de la que desconocemos la datación, pero que ciertamente hubo de ser escrita entre el 19 de mayo fecha de la conquista aragonesa de aquella ciudad, y el 29 de agosto, data del presente traslado) en confirmación de un cierto número de gracias y mercedes, que disfrutaba, por concesión especial de Alfonso X el Sabio, clara síntesis del Fuero que le otorgara este mismo monarca, años atrás, a través de su amplia legislación foral casteIlana, y la de sus sucesores Sancho IV y Fernando IV.

ACA, CC.RR. Diplomáticas, Jaime II, caj. 2, n.ำ 289.

Edit. ESTAL, J.M. del, "Confirmación de fuero a la ciudad y reino de Murcia por Jaime II de Aragón (1296-1304)", Miscelanea Medieval Murciana, IX (1982) 244247; Id., El Reino de Murcia bajo Aragón. Corpus documental, I/1, n.ำ141, pp. 256260 , Alicante, 1985. Hoy brindamos nueva lectura más correcta de algunos términos borrosos y oscuros. Anteponemos un número a cada capítulo para su mayor claridad.

Aquest aço es treslat de una carta en que son escrits los capitols de les graçies e de las merçess que el molt alt e molt noble Sennyor don Jayme per la gracia de deu / Rey Daragon e de Mayorca etc. al Conssell de Murçia, segons que a fet scriure, la qual es sagellada ab lo seu sagell /.

Aquestes son las graçies e merçes quel Conssell de Murçia demanda al Senyor Rey/.

(1) Primerament que en negun temps nols partira de la seu corona ni del seu sennoryu per neguna raho $/$.

(2) Item quels confferm los Furs e Privilegis, franquesses e libertats e merçes e honrres e bons uses que an del Rey Don Alffonsso, qui parays aia, e dels al-/tres qui pus / del regnaren en Castella /.

(3) Item quels confferm la partiçio que fo feyta de Murçia e las donaçions en general e en espeçial, axi quels cascunes coses en(?) (de ?) tal possessio / (o corporal possessio?).

E plau al sennyor Rey, salv dret dun vey a altre $/$. 
(4) Item que perdo tota questio o demanda, que ell pogues fer contra alguns de qualquier raho o malefiçi, que aguessen fet en la sua terra o en terra de Murçia e / tota altra justiçia e pesquises e inquisiçions de qual que raho sien, tro al dia duy /.

E lo sennyor Rey o perdona en quant en ell es tot ço que feyt sia entro / al dia de huy, sia fet en pau o en guerra o en treua. Mas si a algun hom desta terra avien res pres en pau o en treua, quels en façen dret/.

(5) Item que tots les perdons que son feits aixi duneys contra daltres coses ab cartes dels reys o dels adelantats que sien firms $/$.

(6) Item que tots los veys de Murçia sien franchs generalment e per tot lo seu sennyoriu per mar e per terra, axi en ço que havuy an, com daquiavant avran /.

(7) Item quels Jueus, els Moros sien salvs e segurs, elis e tot lo sou /.

E plau al sennyor rey $/$.

(8) Item que tots aquells qui en aquesta avinença ne volrran esser, que axi pusquen anar salvs tot lur moble. E si dins XXX dies volrran tornar a la merçe del rey, que no / perden res del lur. E si lur (borrados: persones fossen axi prestes?) a retornar ab ells, quels romangan salv ab lur dret, e que axi sien enteses jueus e moros /. E si alguns son fora de la terra e al temps dato e dins XXX dies, pus que avran al sennyor Rey, volrran venir a merçe del rey, que non / perden lo seu /.

E plau al sennyor rey del dret que havuy y han $/$.

(9) Item que tots los vehins de Murçia, qui alguna cosa agen en qualquier lugar del Regne, quels sia salv $/$.

E plau al sennyor rey $/$.

(10) Item que tots los plets qui son determenats e passats en cosa jutgada, quier per juy o per cartes del reys, que no pusquen esser altra vegada retrotrats /.

E plau al sennyor rey /.

(11) Item que totes les cartes publiques e les altres escriptures dels plets, ques façen en vulgar pla, per que les gens plus clarament o entenen $/$.

E plau al sennyor rey $/$.

(12) Item que pertoch totes quantes donaçions ell avia fetes o atorgades a alguns de cases o heretaments o de rendes o de qualquier altres coses dels / vehins de Murçia, quels o conferm, axi com cascun n'es en possessio ab cartes del rey o en altra manera $/$.

(13) Senyor, per que entenem que es vostre serviy e de la terra, clamam vos merçe, que puscam traure del Regne pan e vin e totes altres viandes, franques e quites, / e portar en totes parts /, salv en terra de vostres enemics /.

(14) E atressi senyor, quens façats merçe, en lexar nos pendre les rendes del Regne de Murcia, tro que aviam pagats $X$ millia solidorum, quel consell e manlevats per adobar / los murs e les torres de la via e que prestarem a Johan Sanches e als castellans sobre estes rendes. Les quales els teniem e preniem per manament / e cartes del Rey, o quens hi façats aquella ajuda que tingats per be /.

E daquest Capitol parlara en Bernat de Sarria ab ell/.

Senyal (signo notarial) de mi Domingo de Ssoler, notario public de Murçia, qui aquest treslat escriure fiu e comprove con el padro, XXIX dies de agost, / era de mille e CCC e XXXIIII ans / (65). 
1296, julio, 3. Asedio de Elche.

Al mes y medio, poco más, de la conquista de la ciudad de Murcia (19 mayo 1296), Jaime II ordena al justicia de aquel concejo que, en tanto se elabora la compilación del nuevo Fuero de Murcia bajo Aragón, se sirvan del precedente fuero vigente durante la soberania castellana (1243-1296), y que donde no alcance éste a legislar, se ajusten al Fuero de Valencia. Este habrá de ser el procedimiento judicial a seguir por el justicia de Murcia, Pedro Jiménez de Spilonga, pudiendo aplicar la legislación del fuero de uno u otro Reino, de Castilla y Valencia, hasta la promulgación del nuevo, propio, cuya compilación está encomendada a tres juristas conocidos, el canónigo leridano, Raymundo Cabrera, y Martín de Dios y Juan Meeyani, de Meeya, residentes en Murcia, como se desprende de la carta real siguiente.

ACA, Reg. de Regno Murcie, 340, fol. 191v.

Edit. ESTAL, J.M. del, "Confirmación de fueros a la ciudad y reino de Murcia por Jaime II de Aragón, 1296-1304", Miscelanea Medieval Murciana, IX, 1982, n. . XVIII, p. 280. ID., El Reino de Murcia bajo Aragón, 1296-1035. I/1. Alicante, 1985, n. ${ }^{\circ} 113$, pp. 219-220.

Petro Eximeni de Spilonga, justicie Murcie vel eius locum tenenti etc.

Mandamus et dicimus vobis quatenus, donec compilatio / que fieri debet de foro Murcie, per nos universitati Murcie concesso, utamini foro quo utebamini tempore / illustris dompni Alffonsi quondam Regis Castelle, predecessoris nostri in Regno Murcie supradicto, et in eo in / quo dictus forus non sufficeret, utamini foro Valencie, donect dicta compilatio dicti fori Murcie facta fuerit / ut est dictum.

Datum in obsidione Eltxii, quinto nonas julii, anno domini MCCXC Sexto / (66).

\section{3}

1296, julio, 3. Sitio de Elche.

Jaime II de Aragón encomienda a los jurisperitos murcianos, Martín de Dios y Juan de Meeya o Meeyani, la compilación del Nuevo fuero de Murcia, ordenándoles que lo tengan concluido a la brevedad mayor posible, de suerte que pueda tenerlo en sus manos para su próximo viaje a la ciudad de Murcia (primeros días de agosto del mismo año), al objeto de poder revisarlo y efectuar los cambios que estime oportunos.

ACA, reg. c. 340: De Regno Murcia, fol. 191v.

Edit. ESTAL, Juan Manuel Del, "Confirmación de fueros a la ciudad y reino de Murcia por Jaime II de Aragón, 1296-1304", Miscelanea Medieval Murciana, IX, 1982, n. IX, pp. 280-281.

ID., El reino de Murcia bajo Aragón, 1296-1304/5. Corpus documental. 1/1. Ali-

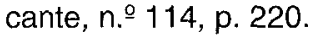


Jacobus, etc.

Fidelibus suis Martino Dei, jurisperito civitatis Murcie et johanni Meeyani, etc.

Mandamus et dicimus quod in compilatione per vos facienda de Foro per nos concesso probis hominibus et universitati civitatis Murcie, caute et diligentissime prout celerius poteritis procedatis.

Taliter faciendo quod cum nos ad dictam civitatem accesserimus dicta recapitulatio sit perfecta et nos super ea possimus facere quod facere haberemus.

Data ut supra (in obsidione Eltxii), quinto nonas julii anno domini M CC XC sexto) (67).

\section{4}

1296, octubre, 25. Tarragona.

Notificación de Jaime II al procurador general del reino de Murcia, Jaime Pérez, su hermano y señor de Segorbe, de haberle enviado el volumen de los fueros de la ciudad y reino de Murcia, hecho compilar con urgencia, a instancia persistente de los hombres probos de la ciudad y otros lugares de aquel reino, por los expertos murcianos en leyes, Martín de Dios y Juan Meeyani, y el jurisconsulto y canónigo leridano, Ramón Cabré o Raymundo Cabrera, en cuatro libros, para cuya promulgación debía trasladarse sin demora a la capital murciana, convocando antes a la misma para aquel singular evento a dos procuradores de cada villa y lugar del reino, procediendo en presencia suya y consejo oficial a abrir y publicar el citado volumen, del que habría de entregar una copia a cada uno de los asistentes mencionados y hacer guardar en la capital el volumen enviado como el original, del que deberían servirse en adelante en exclusiva, en todo litigio, sin recurrir más a otros fueros.

ACA, Reg. c. 253 fol. 3r.

Domino Jacobo Petri, etc.

Cum nos fforos Murcie, quod ad humilem supplicationem et magnam instantiam fidelium nostrorum proborum / hominum civitatis Murcie et aliorum Regni predicti, sub uno volumine, / compilationis ipsorum fecimus compilari, apud civitatem Murcie transmitamus, sub sigilli nostri mu- /nimine interclusos, volumus ac visis presentibus, / omni mora postposita et remota, ad civitatem Murcie vos personaliter transferretis, electuris / ad hoc duobus probis uniuscuisque loci nostri Regni predicti hominibus, qui publico consilio faciatis volumen predictum / aperiri ac etiam publicari.

Quo volumine pro orginali apud civitatem Murcie remanente, singulis quidem / aliis probis hominibus regni predicti et tribuatur et fiat copia de eodem.

Mandantes ex parte nostra sub pena / corporis et bonorum, sicut nos per alias nostras literas duximus iniungendum, quarum tenorem / in fine poni fecimus voluminis supradicti.

Quod nullus in civitatis et regni predictis (locis ?) in judicio vel extra amodo audeat aliis / foris uti. 
Datum Terrachone, VIII kalendas novembris / (68).

\section{5}

1296, octubre 25. Tarragona.

Carta de Jaime II al justicia y jurados de la ciudad de Murcia y demás hombres probos de la misma para notificarles que les ha remitido el volumen de los Fueros de la ciudad y reino de Murcia y que, al objeto de erradicar toda duda que pueda sobrevenir acerca de la confirmación real de los mismos, prohibe cualquier enmienda sobre ellos y les ordena que hagan trasladarlos literalmente en buena y clara escritura caligráfica, en excelente pergamino, con toda fidelidad, debiendo guardar luego tal volumen manuscrito con toda diligencia y esmero, si es que desean mantenerse en su gracia y favor.

ACA, Reg. c. 253 fol. 3 r.

Fidelibus suis justicie et juratis civitatis Murcie, etc.

Dicimus quod fori, quos vobis et aliis probis hominibus / civitatis et Regni Murcie mitimus in uno volumine, qui precipue sunt conscripti / quia de ipsius voluminis facilius confirmatione potest meriti dubitari, idcirco vobis sub pena nostre ire et / alia pena nostro arbitrio perfugienda, firmiter et discrete precipimus et mandamus, volumine aperto predicto, quod enmendatione nulla in hoc / habita, si de nostra gratia confiditis confirmari, foros predictos transcribi de bona et grossa litera de verbo / ad verbum in bono pergameno fideliter faciatis, volumen predictum caute et / cum diligentia reservantes.

Datum Terrachone, VIII kalendas novembre / (1296) (69).

\section{6}

1296, octubre, 25. Tarragona.

Provisión real de Jaime II a favor de la ciudad y reino de Murcia, por la que les notifica que, atendida la petición cursada por sus hombres probos de dotarles de un cuerpo legal nuevo por el que pudieran regirse en sus juicios y demás litigios, les ha hecho remitir un volumen en cuatro libros con la legislación solicitada, compilada al efecto, con la celeridad que el caso requería, por los legistas murcianos Martin de Dios y Juan de Meeya y el jurisconsulto y canónigo leridano Raymundo Caprarii (Ramón Cabré o de Cabrera), debiendo servirse en adelante de este Fuero Murciano Nuevo en exclusiva, conservando el volumen enviado como el original auténtico y haciendo del mismo tantas copias fidedignas, cuantas sean precisas para las distintas villas y lugares del reino.

ACA, Reg. c. 253 fol. $4 \mathrm{r}$ 
Edt. ESTAL, J.M. del, El reino de Murcia bajo Aragón (1296-1305). Corpus documental I/1. Alicante, 1985, n. 148, pp. 272-274.

Nobilibus et dilectis ac fidelibus universis et singulis tam in civitate quam (70) Regno Murcie constitutis, salutem / et gratiam. Pridie dum eramus.in Regno nostro Murcie personaliter constituti, ad humilem supplicationem / et magnam instantiam fidelium nostrorum proborum hominum civitatis Murcie et aliorum regni predicti, diversos foros / diversasque leges seu constituiones in diversa dispersos volumina, ad magnam et evidentem utilitatem / totius Regni predicti per discretos et prudentes Raymundum Caprarii canonicum Ilerdensem et alios quos ad hec specialiter deputavimus in volumine hoc per quatuor libros divisum, quod forus murcie / volumus nominari, resecatis quibusdam superfluis, providimus redigendos, adicientes aliqua etiam per que nonnulla /, que in prioribus (71) eran dubia, declarantur.

Volentes autem ut universi et singuli tam civitatis quam Regni / predicti, tam in judicio quam extra, compilatione hac utantur. Precipimus sub pena corporis et bonorum quod nullus / aliis foris uti presumat, nec aliquam aliam compilationem facere absque nostra auctoritate regia speciali. Quod volumen vobis sub sigilli nostri munimine mitimus interclusum. Volentes quoque et mandantes / quod volumine ipso pro originali apud civitatem Murcie remanente, universis Regni predicti detur / et tribuatur copia de eodem.

Data Tarrachone VIII kalendas novembris / (anno predicto, 1296). Raymundum (per ? Salis, Ramón de Sales, vicecanciller de Jaime II, años 1296-1299, y sustituto del canciller Ramón Despont, obispo de Valencia) tenentem locum venerabilis episcopi Valentie in cancellaria, mandato et nomine dicti Raymundi Pontis et Johannem / de Meeya, jurisperitos / (72).

\section{7}

1308, enero 18. Valencia.

Carta de Jaime II al Consell de Orihuela, notificándole que ha escuchado a sus procuradores, Pedro de Dios y Pedro Malquería, y entendido el asunto que los llevó a su presencia, cuya resolución verán por las cartas reales suyas que portarán consigo. Les anticipa, no obstante, que en lo que concierne al cambio de denominación del fuero de Murcia por el de Fuero de Orihuela, no lo estima aceptable, por ser lo más procedente que se acojan al fuero de Valencia, por tratarse de un forus satis acceptabilis et sufficiens, y hallarse incorporadas sus tierras y gentes al Reino de Valencia ultra Sexonam. Les ruega finalmente que cambien impresiones al respecto en los concejos de Alicante y Elche, integrantes todos de la Procuración General de Orihuela, y deliberen sobre la aceptación del fuero de Valencia, bien entendido que ello no obstará al mantenimiento de los propios fueros locales, que él hará cumplir y respetar severamente por todos. $Y$ que sucesivamente le hagan saber el acuerdo tomado.

Arch. Munic. Elche (AME), arm. 2, Codice, fol. XCVIIlv-XCIXr, nº XCII. 
Edt. ESTAL, J.M. del, "Fueros y sociedad en el Reino de Murcia bajo la soberanía de Aragón, 1296-1304", Anales Historia Medieval, 3, Universidad de Alicante, 1984, p. 124-125, no 2 .

Privilegium quod Rex Aragonie dedit forum Valencie Oriole / salvis omnibus eorum privilegiis /.

Jacobus dei gratia Rex / Aragonum, Valencie, Sar-/ dinie et Corsice Comesque / Barchinione ac sancte romane ecclesie vexi-/ llarius, admirantus et / capitaneus generalis / fidelibus suis Concilio et universitati Oriole / salutem et gratiam.

Vidimus Petrum de Deo et Petrum Malquería /, nuncios vestros quos / ad nos cum licteris (sic) de / credencia et quibusdam / capitulis transmissistis / et intellectis hiis que / in dictis licteris (sic) et cap- / pitulis continebantur / et que ipsi nuncii no/bis ex parte vestra ex-/ponere voluerunt, con-/cessimus et fieri iussi-/mus cartas nostras et tradi dictis numpciis (sic), ut / in eis videbitis contineri.

Preterea super / facto fori vestri qui / nuncupatur forus Murcie /, quemque velletis / nominari forum Oriole /, vobis respondendo / significamus quod, quia forus $\mathrm{Va}-$ lencie est sa-/tis forus acceptabilis et sufficiens, placeret nobis / quod vos et alie universitates terre nostre / ultra Sexonam forum ipsum Valencie haberetis /, privilegiis vestris salvis.

Quare volumus et / mandamus quatenus una cum conciliis Alacan-/tis et Elchii super habendo dicto foro Valencie / conveniatis ac etiam conferatis. Et habita colla/ tione super eo, curetis nos inde reddere cerciores /.

Data Valencie, quinto decimo kalendas februarii, anno / domini M CCC septimo / (Entiéndase año 1308 por seguir la cancillería aragonesa la datación por la Era Incarnationis, estilo florentino).

1301, febrero, 18. Murcia.

Reedición y retoque del Fuero Nuevo de Murcia por Jaime II de Aragón, bajo la denominación de Constitutiones Regni Murcie, en las que, a petición de los hombres probos de la comunidad murciana, incorporó ciertas "declarationes et additiones, correctiones, substractiones et mutationes", las que habrán de añadir al precedente Fuero Nuevo del 1296 y atenerse en lo sucesivo a su normativa estrictamente.

ACA, reg. c. 198 fols. 262r-265r.

Carta inédita.

CONSTITUTIONES REGNI MURCIE /.

Jacobus dei gratia rex Aragonum, Valentie et Murcie ac comes Barchinone, dilectis et fidelibus suis / procuratori, baiulis, justiciis, alcaldis et aliis officialibus et subditis nostris Regni Murcie, presentibus / et futuris gratiam et benevolentiam suam in perpetuum. 
Cum ad officium regale pertineat jura tenere / nec minus condita declarare, idcirco fidelitati ac devotioni vestre serie presentium intimamus quod nos / ad supplicationem proborum hominum et universitatis civitatis Murcie, pro se et aliis universitatibus / regni Murcie nobis supplicantium in hac parte quasdam pro utilitate regni Murcie nobis supplicantium in hac parte quasdam pro utilitate regni ipsius fecimus decla- / rationes et additiones, correctiones, subtractiones (sic) et mutationes in foris sive legibus specialibus dicti / regni, quos (foros) olim (a.1296) edidimus, quasque (adiciones) vobis sub nostri sigili munimine mittimus infrascriptas.

Quocirca / vobis et cuilibet vestrum dicimus et mandamus quatenus dictis declarationibus, additionibus, correctionibus, subtractionibus et mutationibus, sicut inferius continetur, prout casus emerserint utamini in judiciis et extra /, ipsasque (tales adiciones nuevas) in volumine fororum (al volumen del Fuero Nuevo en cuatro libros) predictorum seu legum adiciendo (incorporándolas al mismo), observetis ac faciatis ab omnibus in-/ violabiliter observari.

Declarationes, additiones, correctiones, subtractiones et mutationes / predicte sunt hec que sequuntur.

( $Y$ a continuación añade en valenciano las CONSTITUTIONES REGNI MURCIE que reproducimos seguidamente).

En la Rúbrica de la Cort en la ley que comença: "La Cort / (2) en sa pròpria persona en la casa etc." là on diu: "que oja e termén, pledeig e defenesca ab consell / (3) dels assessors e dels prohòmens de la ciutat tots los plets criminals e civils e tots los / (4) clams qui seran en la ciutat e en tot lo terme etc.", declara lo Senyor Rey que ja.sia / (5) que la dita ley parle generalment, emperò lo Procurador General del Regne per son offici o / (6) altre official del senyor Rey o persona a qui lo senyor Rey o comanàs, poden demanar / (7) e punir per si e sens la cort o la justícia de la ciutat o qual ques.vol loc, crims de / (8) heretgia e de lesa magestat e de quayx lesa magestat en los cases dejús expressats e / (9) encara altres crims que emportassen per sa natura demanda o confiscació de béns al senyor Rey / ( 9 bis) o si iniuria corporal era feta a oficial del senyor Rey a lurs familiars domèstics, / (10) com estes coses sien regalies del senyor Rey,

E encara declara lo senyor Rey que si Procu- / (11) rador seu General de tot lo Regne serà en la ciutat o en alcú loc del Regne e per bé de / (12) les gents e per espeegament dels pleyts volran que els plets sien hoÿts denant si per la / (13) justícia del logar, que o pusca fer si.s vol sien los pleyts criminals o civils; salvant emperò / (14) que si.ls prohomens de la ciutat o dels locs per privilegi o per custum deuen esser als // fol. 262v (15) juhís e les sentències que hi solen aver vou, que hi sien appellats per lo procurador, axí como foren per/(16) justícia si.l procurador no.y fos.

Encara que si bé lo procurador oyrà quels plets e.ls farà / (17) deliurar e espeegar, que emperò los procés d'aquels plets e les sentències sien escrits e escrites / (18) al libre de la justícia e sien dictades e donades les dites sentències en perssona de la justícia, con que / (18 bis) la justícia deya esser obedient al procurador en espegar e en donar les dites sentències, axí com / (18) lo procurador trobarà de consell en la presència de la justícia esser faedor. E axí tinga que.l / (19) procurador aquesta audiència no pusca a altre comanar, mas que ell personalment y pusca / (20) esser quant se vula, segons que dit és; si doncs no eren fets de vilves o 
de pubils o de / (21) persones miseràbles, los quals fets lo senyor Rey, sens perjudici de la dita ley, pot comanar / (22) o des a qui.s vula o els procuradors si.s vol los plac hoyr per si o comanar a seu loc-/ (23) tinent general del Regne, mas no a altre delegat en especial. Açò emperò / (24) entés lo senyor Rey que.s fassa si les dites vilves, pubils o persones miseràbles (les quals / (25) fets lo s.[- - -] o requirran e no en altra guisa.

Encara que sens prejuhi de la dita ley, lo / (26) procurador del Regne pot demanar e enquerre e punir per si o per altre contra los offi-/ (27) cials del senyor Rey o seus e lurs loctinents axí passats com pressents. E per tal<s> ca- / (28) sos damunt és dit que.l procurador pot demanar e punir per i crim de lesa magestat / (29) e de quaix lesa magestat e el dit crim haya moltes branques e caps.

No entés lo senyor Rey que de tots / (30) lo procurador se puixa entremetre sinó d'aquests qui.s seguexen:

Primerament, ço que / (31) Déus no vula, si alcú contra la magestat del senyor Rey 0 de la Senyora Reyna 0 de sos / (32) fills tractarà, consintrà 0 farà 0 darà obra, ajuda o consell en alguna cosa que manifes / / (33) tament o amagada tornas en lesió de lurs persones.

Item, si alcú serà en tractament $0 /(34)$ en consell o en ajuda o en obra 0 en consentiment o que fassen perdent al senyor Rey, / (35) Regne e ciutat, vila o castell o altre logar, per què lo senyor Rey se pogués minvar / (36) de sa senyoria e sos enemics crexeren, o si alcú se alsava ab alcú d'aquels lochs contra / (37) la voluntat del senyor Rey o retenia alcaydia o altre offici que.I senyor Rey li agués i (38) comanat, o altre per ell contra sa voluntat.

Item si alcú serà en tractament o en con- / (39) sell o en ajuda o en obra o en consentiment que alcú conseller o official o ministre / (40) d'aquells qui guarden e provexen e pròpriament lo cors del senyor Rey e de la // f. 263r (41) Senyora Reyna $o$ de sos fils o encara altres officials qui tenguen jurisdicció ordinària e.l Regne / (42) prenen algun dan en lurs persones.

Item si serà feta conjuració o conspiració entre alcuns / (43) contra la cosa pública de la ciutat a dels altres locs on seran.

E tots los damunt dits cases / (44) entés lo Senyor Rey que.I procurador pusca demanar e punir per si per crims de lesa magestat, etc. I

(45) Item entés lo senyor Rey que.I dit procurador pot demanar e punir per si, axí com crim de quaix / (46) lesa magestat, crim de falsa moneda o de privada carçre, e si alcú falsarà lo segell o les / (47) cartes del senyor Rey o de son official en qui fos la magestat o el senyal configurats del / (48) senyor Rey o nom d'aquell senyor Rey o de la sua dignitat escrit o nomenat.

Item entes lo / (49) senyor Rey que.l procurador o son loctinent se pot entremetre e conèixer dels plets civils e / (50) criminals, qui sien en curials o soldaders qui no sien de la ciutat. Mas si los sol- (51) daders són vehins de la ciutat o dels altres locs del Regne, no sien separats de la / (52) jurisdicció de la cort o de la justícia d'aquells locs en altres cases sinó en aquels qui per- / (53) tanguessen al feyt de les armes per rahó del sou o de lurs cavalcades. E açò mateix entés lo / (54) senyor Rey: ço és, que pertanyent a offici de procurador o de son loctinent altres hò-/ (55) mens estrangers qui fossen / (56) venguts al senyor Rey e lurs companyes. 
Axí emperò entés lo senyor Rey les damunt / (57) dites coses, que si les dites persones havien demandes entre si o seran demanats per al- / (58) guns de la ciutat o del Regne, que la conexença dels dits fets, axí com damunt són / (59) declarats, pertanga al procurador e a son loctinent.

Mas si ells demanaven a altre / (60) de la ciutat o del Regne que hayen a pendre d'ells dret en poder de la cort o de / (61) la justícia del loc on seran demanats.

Item en la Rúbrica de convinençes e de conspira- / (62) cions en la ley que comença: "Si.l creedor retrà al deutor la carta, etc.", enedeix / (63) e ajusta lo senyor Rey aquestes paraules: "e és presumpció esser retuda la carta / (64) al deutor per lo creedor, si aquella carta serà trobada tayllada en poder del / (65) deutor".

Item en la Rúbrica de Juhiis, en la ley que comença: "Alcú no pusca recusar I (66) la cort, etc.", enedeix e declara lo senyor Rey, segons que.s segueix, que en tot fet / (67) criminal en què la justicia o jutge delegat aja a fer inquisicions, que la cort sia tengut / (68) d'apellar a les confessions e als testimonis a pendre, e un dels jurats qual que els $/ / \mathrm{f}$. 263v. (69) escullirà e tenrà altre prohom de la ciutat o del loc, axí emperò que.I jurat e aquell prohom / (70) sien tenguts d'esser en aquell loc on la cort o el jutge faran la inquisició e que la / (71) cort los ne puxa destrényer. $E$ que sia entés que hi sien los dits jurats e prohom per nom / (72) del senyor Rey. E axí faent e posant en los feyts criminals aquell jutge ordinari / (73) ne sos assessors no pusquien esser recusats.

Item quant als fets civils que sia enantat / (74) en aquesta manera: que si el jutge ordinari serà recusat, que basta al recusador que a entés / (75) justa rahó de suspita denant ell. E jurant que no la posa per malea ne per lo greujar / (76) o difuyta de plet e que no li cayla aquella provar, mas en continent que sia acompanyat $/$ (77) con altre bon home no suspitós al dit jutge ordinari, lo cual sia elet ab volontat / (78) de les parts, si acordar se'n poran abdosos en presència del jutge. En altra manera / (79) si acordar no se'n podien que.ls assessors abdosos a là on no ha mas un assessor / (80) e aquell assessor ab lo jutge que.l elegeix e li assignen. $E$ axi aquell acompanyat ab lo / (81) jutge ordinari, ensemps ab consell del assessors o assessor, que enanten en lo fet $\mathrm{e} /(82)$ segons que serà faedor.

Item que si jutge serà delegat, serà recussat, que.l / (83) recusador aja a allegar ans del pleyt comensat justa rahó de recusació, de la qual / (84) si és vera o no, sien elets àrbitres per les parts que.n coneguen d'una part e segons / (85) covinent assignador per lo jutge ordinari. E si la recusació serà trobada e jutgada esser / (86) vera e justa, que aquell delegat sia remogut e altre assignat. E si la recu-/ (87) sació serà trobada esser falsa o no justa, que feyta condempnació en les despen- $/$ (88) ses contra aquell qui la aurà posada, que.l jutge que enant e.I fet segons que / (89) rahó serà. E axí que tots los furs qui parlen en recusació de tots jutges / (90) que sien enteses esser corregits en aquesta present declaració.

Item en la Rúbrica / (91) de contestació de plets sobre la derrera líg, on diu "que totes excepcions / (92) peremptòries sien posades dins deu dies despús la demana serà contestada, / (93) etc." E declara lo senyor Rey que tota excepció peremptòria sia posada dins / (94) X dies contínuus, útils o no útils aprés de la lit contestada e puys neguna / (95) non sia rebuda si doncs aquel qui la posarà, non jurarà que aquella excepció / (96) que vol puys posar, no sabia en temps de la lit contestada, nen dins los // f. $264 r$ (97) dits $X$ dies e que de novell la ha sabuda e que no la posa 
per raó de trigar lo plet ne per / (98) malícia, mas que crou que li deya ajudar en son dret. E ab aytal sagrament sia reebuda tota / (99) excepció peremptòria pertanyet e coneguda del jutge entró a conclusió feyta del pleyt.

Item / (100) en la Rúbrica de demandes e obligacions, a la ley que comença: "Si alcú se obligarà a / (101) altre ab carta o menys de carta, etc.", declara lo senyor Rey que si bé los béns d'alcú no / (102) seran obligats nomenadament e que gens per aço no romanga que dels béns d'aquell qui / (103) serà deutor o obligat, no sia feita entegra a sos creedors, salvant prioritat de temps e / (104) pocioritat de dret a altres creedors si y són.

Item en la Rúbrica que parle de tudors / (105) e de curadors, fa lo senyor Rey e enadeix aquesta ley: Si alcú se absentarà e per la longa / (106) absència és estat absent o se serà fama o opinió que fos absentat en frau de sos creedors, la cort / (107) a instància de sos creedors deu donar curador als béns d'aquell absent qui defena e / (108) respona per aquell.

Item enadeix lo senyor Rey en aquesta Rúbrica la ley que.s segueix: Si.l tudor / (109) 0.1 curador o encara la mare o altre parent d'alcú menor en poder d'él, en regiment del qual / (110) estarà o serà comenat, afforrarả lo menor, à mester a acelerar servey a cert temps. Lo menor / (111) no pot revocar lo contract dins edat de XIV anys, sia home o fembra. Mas d'aquí avant (112) és en sa volontat d'estar a aquell contract o no.

Item en la Rúbrica de testaments, en la ley / (113) que comença: "Com no sia neguna cosa, etc. ", là on són aquestes paraules: "partesquen e donen" / (114) corregeix lo senyor Rey que en loc d'aquelles paraules sien aquestes paraules: "pusquen / (115) partir e donar". E aprés aquelles paraules qui dien en la dita ley: "eguals e no eguals", / (116) que sien ajustades aquestes paraules: "o altres persones a qui.s volran".

Item en la Rúbrica / (117) de appellacions, en la ley que comença: "Tots los plets e les demandes, etc.", là on diu: "Mas / (118) en les segones apellacions sien tenguts d'apellar e de venir a nós les parts e no davant / (119) altre, etc.", de gràcia penal atorga lo senyor Rey e declara la dita ley en aquesta manera: Que / (120) mentre ell sia en la ciutat o el Regne de Múrcia que les segones apellacions venguen / (121) en tot cas a ell e a sa cort. Mas si el senyor Rey serà fora lo Regne de Murcia $0 /$ (122) haurà Procurador General en lo dit Regne, son loctinent general que sia en volontat / (123) d'aquell qui se apellarà de appellar-se e d'anar al senyor Rey là on sia o al dit procurador // f. 264v (124) e a son loctinent general qual més vula. E encara declara, atorga de gràcia lo senyor Rey / (125) que.ls delmes qui exiran de les sentències donades en la cort de la justícia finalment serà / (126) aprovada e que aquella sentència pas en cosa jutgada, prena la justícia qui haurà dada la primera sentència / (127) e mene aquelia sentència a exequció. Si emperò la sentència de la justícia serà revocada e obtendrà / (128) la sentència del procurador, en aquest cas reeba los delmes lo procurador e qui.n rerà compte / (129) aquí tambè, com la justícia faria si.Is prenia a leu la sentència a exequció.

Item en aquels cases que / (130) dit és dessús, que.l procurador o son loctinent podien conèxer per si sens la justícia, atorga lo / (131) senyor Rey de gràcia que en les primeres apellacions deja assignar jutge axí como faria la justícia / (132) per 
ço que les gents en null cas no los cayla exir fora lo Regne per les primeres apellacions. /

(133) Item en la Rúbrica de Eviccions, declara lo senyor Rey la ley que comença: "Lo venedor / (134) dou deffendre en dret lo comprador, etc.", on si aquell qui serà nomenat per antor serà / (135) present, que sia observat lo fur antic, com aquell fur parle solament segons que apar entre / (136) presens. E si per aventura serà absent, que sia dat termini de trenta dies en contíuues / (137) províncies o de quatre meses, si serà esser dit en províncies lunyadanes quals.se.vol / (138) sien. Axí que si dins los dits terminis no serà deffés per lo dit antor aquell qui.I nomenarà / (139) que pus enant no sia esperat, ans sia enant e.l pleyt segons que rahó serà. Axí que penjant / (140) la dita dilació no sia en res enantat, ans sia sobresehit. E que en cada un de los cases / (141) damunt dits a qui serà dada dilació sia feyt sagrament de calúmpnia o de malícia per aquell / (142) a qui serà dada.

Item en aquella mateixa Rúbrica enedeix lo senyor Rey aquesta ley: Si la / (143) cosa d'alcú deutor serà venuda per la cort per pagar sos deutes als creedors o donada / (144) en paga als dits creedors: si aprés d'açò d'aquella cosa serà feyta demanda contra / (145) los dits creedors o compradors si.l deutor de qui la cosa fo serà present dins / (146) lo Regne de Múrcia, deu-li esser feta denunciació que defensa los dits possehidors / (147) de la cosa. En altra manera, si serà fora lo Regne, no li són tenguts los compradors / (148) o els credors damunt dits, que li o denuncien, 0 ans si perden lo pleyt per dret o per / (149) fur, ayen regrés de evicció contra lo deutor de qui fo la cosa.

Item en la Rúbrica de malfeytors, en la ley que comença: "Si alcú cavaller desafiarà / (150) altre cavaller, etc.", là on diu: "e si.l matarà acordadament o.I nafrará // fol. 265r (151) o alcú mal o dan a ell o a les sues coses farà o darà menys de desafiament, que sia traÿdor", / (152) declara lo senyor Rey que si matarà acordadament o nafrarà o ferrà ab nafra o sens / (153) nafra o li pendrà Vila o Castell o Torre o Casa o la derrocarà o la cremarà sens desafia- / (154) ment, que en aquests cases sia traÿdor. Mas si no o farà acordadament en los dits cases / (155) o altres dans darà o farà en béns mobles o seents oltra los cases damunt espressats, 1 (156) si bé o farà acordadament que o estimen en .IIII. dobies, de la qual pena de .IIII. dobles / (157) aja la meytat lo senyor Rey e la altra meytat aquell qui.l dan aurà pres. Ajusta emperò / (158) lo senyor Rey a la dita ley que si per aventura alcú dels damunt dits desafiats ree- / (159) brà o acceptarà los desafiaments, que en aquest cas lo senyor Rey o son procurador del / (160) Regne o justícia o altres officials qui sien per lo senyor Rey en aquell loc, per nom del senyor rey / (161) pusca donar seguritat entre les parts axí com a ell sia vijares e forssar règea- / (162) ment les parts a tenir la segurtat damunt dita.

Item declara lo senyor Rey en la dita / (163) ley que tot mal que sia fet dins treva entre les persones en la dita ley contengudes, / (164) si.s vol sia fet en persones e en béns, si provar se pot ab dos testimonis covinents o ab / (165) pus, que non sia pres escondiment de batayla d'aquell qui serà demanat de la treva, / (166) ans pus provar se pusca, sia en continent condempnat aquell qui.| dan aurá donat, / (167) ço és, que si haurà forfet en persona o en béns, que sia traÿdor o tengut de fer es-/ (168) mena de .Illi. dobles, segons la declaració damunt dita posada en aquels qui forfan / (169) entre si, sens desafiament. E que d'aquests cases sia co- 
negut breument e de pla / (170) sens sollempnitat de plet. Salvs emperò sos justs defeniments als demanats si.ls / (171) haurà. E si per aventura en los dits cases, ço és, del mal que.s farà dins / (172) treva, no.s podia fer prova segons que dit és, que en defalliment de la prova lo / (173) demanador pusca aportar a batalla lo demanat. Encara declara lo senyor / (174) Rey que en les demandes o acusacions que.s faran per les dites rahons segons les / (175) damunt dites declaracions. que.l demanador o.l acusador no.s hayen a escriure / (176) a talió.

Data littera et declarationes, additiones, correctiones, substractiones et mutationes / (177) facte et perlate duodecimo kalendas martii in civitate Murcie, anno domini M CCC. (= 18 de febrero de 1301) (73). 



\section{NOTAS}

(1) Una exposición amplia de la conquista del reino castellano de Murcia por Jaime II de Aragón puede hallarla el lector en ESTAL, Juan Manuel del, Conquista y anexión de las tierras de Alicante, Elche, Orihuela y Guardamar al Reino de Valencia por Jaime II de Aragón. Alicante, 1982, passim; Id. "Fueros y sociedad en el reino de Murcia bajo la hegemonía de Aragón, 1296-1304", Historia Medieval. Anales de la Universidad de Alicante, n. ${ }^{\circ}$ 3, Alicante, 1984, pp. 99-130; Id. El Reino de Murcia bajo Aragón (1296-1304/1305). Corpus documental I/1. Alicante, 1985 y I/2 Alicante, 1990, passim; Id. Alicante de villa a ciudad (1252-1490). Alicante, 1990, pp. 23-42 más la bibliografía citada.

(2) Discursos históricos de la muy noble y muy leal ciudad de Murcia y su reino. 4. ${ }^{\mathrm{a}}$ ed. Murcia, 1980 , pp. $75-90$.

(3) MARTINEZ FERRANDO, J. Ernesto, Jaume // o el Seny català, 2.. ed., Barcelona, 1963, p. 151

(4) GONZALEZ MINGUEZ, César, Fernando IV de Castilla (1295-1312). La guerra civil y el predominio de la nobleza. Vitoria, 1976, p. 102; VILAR, Juan Bta., Historia de la ciudad de Orihuela. Los siglos XIV y XV. Orihuela, 1977, p. 243; TORRES FONTES, Juan, "Murcia castellana" en Historia de la Región Mur. ciana, III, Murcia, 1981, p. 379. FERRER I MALLOL, M. ${ }^{a}$ Teresa, Organització $i$ defensa d'un territorio fronterer. La Governació d'Oriola en el segle XIV. Barcelona, 1990, passim; Id. "Notes sobre la conquesta del regne de Murcia per Jaume II (1296-1304)", Homenatge a la memòria del Prof. Dr. Emilio Saez, Barcelona, 1989, 27-44.

(5) Vid. Acta de sumisión en ESTAL, El reino de Murcia... pp. 48-54 y 176-179.

(6) El reino de Murcia... pp. 3-103 y l/2, passim.

(7) Estal, Ibidem, pp. 87-103 y 362-386.

(8) Ibidem, pp. 389-390.

(9) Ibídem, pp. 96-99 y 420-424.

(10) ESTAL, "Nuevos datos sobre la capitulación y conquista aragonesa de Lorca", Homenaja al Prof. Juan Torres Fontes. Vol. I. Universidad de Murcia, 1987, pp. 431-464.

(11) A.C.A., reg. 340:De regno Murcie, f. 191v. Vid. texto completo en Anexo documental adjunto n. .2 . ESTAL, Alicante de villa a ciudad... pp. 26-30.

(12) IGLESIA FERREIROS, Aquilino, "Fuero Real y Especulo". A.H.D.E. LII, 1982. pp. 136-141; PEREZ MARTIN, Antonio, "El Fuero Real y Murcia", A.H.D.E. 
LIV, 1984. p. 82 y pp. 90-92; TORRES FONTES, Juan, Documentos para la historia del reino de Murcia. Murcia, I, 1963, pp. 17-21 y 43-47.

(13) PEREZ MARTIN, op. cit. pp. 90-92, donde abunda la certificación documental de dicho aserto a partir sobre todo del 1266.

(14) IGLESIA FERREIROS, op. cit. pp. 136-143 y 172-176. Y muy en particular Antonio PEREZ MARTIN, op. cit. pp. 90-96.

(15) PESET I REIG, Mariano. "Alfonso X y el Fuero de Alicante", Studia Historica in honorem Vic. Martinez Morella. Alicante, 1985, p. 306; MARTINEZ DIEZ, Gonzalo, Fuero Real, estudio y análisis crítico, Ávila, 1988, pp. 104-106.

(16) PEREZ MARTIN, A. op. cit. pp. 92-93.

(17) Vid. supra nota 11.

(18) A.C.A., reg. 340: De regno Murcie, f. 191v: "Jacobus etc. fidelibus suis Martino Dei jurisperito civitatis Murcie et Johanni Meeyani etc." Vid. anexo documental, $n .03$.

(19) Ibídem. Jaime Il permaneció en la ciudad de Murcia desde el 30 de julio al 4 de agosto de aquel mismo año 1296. Vid. nuestro Itinerario de Jaime /I de Aragón. Vol I, años 1291 al 1304, los días referidos. ( En prensa ).

(20) Vid. supra nota 17 y nota 11, mas A.C.A. C, reg. 253, f. 4r. Anexo documental,

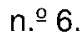

(21) Tras la capitulación de la ciudad de Murcia (19 mayo 1296) el consell de aquella capital elevó al monarca la petición siguiente: "Aquestes son les graçies e merçes quel consell de Murcia demana al sennyor rey:...quels confferm los furs e privilegis e franquesses e libertats e merçes et honrres et bons usos que an del rey don Alfonso, que parays aia, et dels altres qui pus del regnaren en Castella". A lo que respondió complacido afirmativamente el monarca: "E plau al sennyor rey", A.C.A. CC. RR. Diplomáticas, Jaime II, caj. 2, n. 9289 . Vid. ESTAL, El reino de Murcia... n. 9141 , pp. 256-260.

(22) Vid. supra nota 11.

(23) A.C.A., reg. 340: De regno Murcie, f. 191. Vid. Anexo documental, n.⒉ Así se lo impone tasativamente Jaime II al justicia de la capital murciana, Pedro Jiménez de Spilonga, ordenándole que cuantas veces no encuentre la legislación puntual deseada en el Fuero Real murciano, que acuda sin vacilar al Fuero de Valencia, en el que hallará, por cierto, la respuesta judicial esperada, correspondiente al caso en cuestión, a modo de complemento jurídico perfecto del fuero murciano.

(24) Vid. Anexo documental, n. 2. Los jurisconsultos a los que Jaime II encomendó la compilación del Fuero Nuevo de Murcia fueron Ramón de Cabrera o Cabré, canónigo leridano, y los jurisperitos murcianos Martín de Dios y Juan Meeya o Meeyani. Vid. supra not. 18 y Anexo documental, núms. 3 y 6.

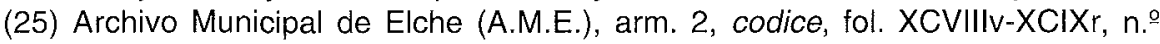
XCll. Estal, "Fueros y sociedad en el reino de Murcia bajo la soberanía de Aragón, 1296-1304", Historia Medieval. Anales de la Universidad de Alicante, n.․ 3, Alicante, 1984, pp. 124-125, n.ำ.

(26) ESTAL, Conquista y anexión de las tierras de Alicante al reino de Valencia por Jaime I/ de Aragón. Alicante, 1982, pp. 294-302.

(27) ESTAL, Alicante de villa a ciudad... pp. 36-38, más los textos citados en nota precedente. 
(28) ESTAL, "Historia Política", en Historia de la Provincia de Alicante, Alicante, 1985, pp. 230-231. Id. Conquista y anexión... pp. 294-302. Id. "Las Instituciones políticas de la villa de Alicante, 1252-1490", en Historia Política ( Cuadernos del diario Información n. 11, Alicante, 1989, pp. 201-220. Id. Alicante de villa a ciudad... pp. 34-40.

(29) Vid. supra notas 10 y 11 con el texto correspondiente respectivo.

(30) A.C.A., reg. 340: De regno Murcia, f. 191v. ESTAL, "Fueros y sociedad en el reino de Murcia...", Doc. XIX, pp. 280-281.

(31) ESTAL, Itinerario de Jaime // de Aragón, Vol. I, meses de julio y agosto del año 1296. En prensa.

(32) A.C.A., reg. 253 , f. 4 r.

(33) A.C.A. CC. RR. Dipl., Jaime II, caj. 2, n. 289. Vid. supra nota 21.

(34) A.C.A. CC. RR. Dipl., Jaime II, caj. 2, n. 289 . ESTAL, El reino de Murcia bajo Aragón... pp. 256-260, n. 141.

(35) Vid. Anexo documental, 2 y 3.

(36) Desde el 3 de julio del 1296, fecha en la que encomendó Jaime II la compilación del citado Fuero Nuevo de Murcia a los tres jurisconsultos referidos, al 25 de octubre del mismo año, fecha en que lo remitió ya concluido al procurador general del reino de Murcia, Jaime Pérez, su hermano, para su publicación y promulgación.

(37) A.C.A., reg. 253 , f. 3r.

(38) Tras ordenar el monarca al procurador general del reino de Murcia que haga guardar el texto original del Nuevo Fuero de Murcia en lugar bien seguro, le manda que haga realizar copia fiel del mismo para entregar a cada uno de los procuradores de los distintos lugares y villas del reino: "Quo volumine pro originali apud civitatem Murcie remanente, singulis quidem aliis probis hominibus regni predicti et tribuatur et fiat copia de eodem". A.C.A. $C$, reg. 253 , f. 3 r.

(39) A.C.A. reg. 198, ff. 262r-265r. Constitutiones Regni Murcie. Vid. Anexo 8.

(40) A.C.A., reg. 253, f. 3r: "idcirco vobis (justicie et juratis civitatis Murcie) sub nostre ire et alia pena...precipimus et mandamus, volumine (del Fuero) aperto predicto, quod emendatione nulla in hoc habita...foros predictos transcribi de bona et grossa litera de verbo ad verbum in bono pergameno fideliter faciatis, volumen predictum caute et cum diligentia reservantes".

(41) Vid. notas 12-16.

(42) A.C.A. C, reg. 253, f. 3r. Vid. supra, notas 12 a 16 y textos respectivo. Vid. Anexo documental, 4.

(43) ESTAL, El reino de Murcia... pp. 262-306.

(44) A.C.A., reg. 198, f. 262 r. Vid. Anexo documental, 8 (protocolo en latín). Entre otros parrafos reproducimos el siguiente: "Cum ad officium regale pertineat jura tenere nec minus condita declarare, idcirco fidelitati ac devotioni vestre serie presentium intimamus quod nos ad supplicationem proborum hominum et universitatis civitatis Murcie, pro se et aliis universitatitus regni Murcie nobis supplicantium in hac parte quasdam pro utilitate regni ipsius fecimus declarationes et additiones et correctiones, substractiones et mutationes in foris sive legibus specialibus dicti regni, quos (foros) olim eddidimus (Fuero Nuevo del 1296) quasque vobis sub nostri sigilli munimine mittimus infrascripta", satisfaciendo así la demanda unánime municipal de una nueva revisión de los fue- 
ros del reino de Murcia, recogidos en el nuevo fuero concedido cinco años antes.

(45) A.C.A., reg. 198, f. 262 r, donde certifica el monarca a los destinatarios aludidos del reino de Murcia que las adiciones, supresiones, correcciones y mutaciones de ciertas rúbricas concretas del fuero nuevo que ahora les envía, deben añadirlas a aquel fuero del 1296, como apéndice complementario al mismo "Ipsasque additiones et correctiones in volumine fororum predictorum (del 1296) seu legum adiciendo (añadiendo) observetis ac faciatis ab omnibus inviolabiliter observari".

(46) A.C.A., reg. 198, ff. 262r-265r. Vid. Anexo documental, 8.

(47) Ibid., fol. 262r. Vid. Anexo documental, 8.

(48) A.C.A., reg. 198, f. 263v. Vid. Anexo documental, 8.

(49) A.C.A., reg. 198, f. 264v-265r. Vid. Anexo documental, 8.

(50) lbídem.

(51) Edición Vicent García Editores S.A. de Arcadi Garcia Sanz, Valencia, 1979, p. 26. En el texto del Fuero de Murcia figuraba aquí un etc., alusivo a la referencia que se hace en los Furs valencianos a la Casa-panteón de los reyes sarracenos de Valencia, cuyos términos reproducimos en el texto sin subrayar.

(52) Términos sin subrayar por no hallarse en el Fuero de Murcia reproducidos.

(53) Els Furs. Vicent Garcia Editores, S.A., por Arcadi García Sanz, Valencia, 1979 , p. 26. Texto subrayado, idéntico en Furs y Fuero.

(54) Vid. Anexo documental, 8 , lineas 3 y 4.

(55) Vid. Anexo documental, 8, linea 62: "Item en la Rúbrica de convinençes e de conspiraçions en la ley que comença: =Si.l crehedor retrà el deutor la carta etc. $=$

(56) Els Furs, p. 38

(57) Anexo documental, 8, lineas 63-65.

(58) "Com non sia neguna cosa que mes sia deguda als homens: que hajen poder en lur darrera voluntat de partir e de ordenar lur coses, etc.", Els Furs, p. 131.

(59) Constitutiones Regni Murcie. Vid Anexo documental, 8, lineas 113-116.

(60) Els Furs, p. 197.

(61) Fuero Nuevo de Murcia, vid. Anexo documental, 8, lineas 118 y 119.

(62) Ibídem, lineas 119-124.

(63) Els Furs, p. 197.

(64) Constitutiones Regni Murcie, vid. Anexo documental, 8, líneas 154-155. Vid. supra notas 46 y 47 , con su texto correspondiente.

(65) La importancia de este traslado notarial es de un valor extraordinario, por atestiguarnos la existencia de un Fuero castellano en Murcia, otorgado por Alfonso $X$ el Sabio y sus dos inmediatos sucesores, Sancho IV y Fernando IV, y la vigencia del mismo en agosto del 1296, fecha en que el Consell de la ciudad solicita al monarca aragonés, Jaime II, quien la había conquistado el 19 de mayo anterior, su visto bueno y real confirmación, a lo que accede complacido el soberano.

(66) La condescendencia del monarca aragonés con el importante concejo murciano no puede ser mayor, accediendo complaciente a que sigan rigiéndose en la administración de la justicia por el viejo fuero castellano, hasta que reciban el nuevo suyo propio, en proceso de elaboración, pudiendo suplir sus defi- 
ciencias con el fuero valenciano. $Y$ es que la resistencia armada que estaba ofreciéndole la población del Reino de Murcia, fiel a Castilla, no era desdeñable en modo alguno y Jaime II debía emplear todos los medios a su alcance para ganarla a su causa. $Y$ el respeto a sus tradiciones y viejas usanzas jugaban un papel estratégico de primer orden.

(67) Sabemos por otra carta real posterior (vid. Anexo documental, n. 9 6) del 25 de octubre de este mismo año, 1296, dirigida a sus nuevos súbditos del reino de Murcia, que participó también en la compilación de este Fuero murciano el canónigo leridano, Ramón de Cabrera o Caprarii (Cabré) en colaboración de los dos jurisconsultos citados de esta carta.

(68) La datación es la del año 1296, por ser ésta la del fol. precedente, 2v, consignada explicitamente en estos términos "anno domini M CC XC sexto" y por seguir remitiendo a aquélla con la fórmula usual de ut supra en los folios inmediatos siguientes.

(69) Es de singular interés informativo esta carta al concejo murciano, por revelarnos la colación por esta fecha de un Fuero a la ciudad y Reino de Murcia por el monarca Jaime II de Aragón, hecho compilar con urgencia, en menos de cuatro meses ( del 3 de julio al 25 de octubre del 1296 ) y a petición de la propia capital murciana y otros lugares de aquel reino, y la obligación de tenerlo como auténtico y de hacer del mismo tantas copias en buena escritura y en pergamino, cuantos eran los lugares y villas del Reino murciano que habían de hacerse representar en la capital del Segura por sus dos procuradores convocados a la misma por el Procurador General del Reino de Murcia, Jaime Pérez, hermano del monarca y señor de Segorbe, al objeto de proceder ante él a la apertura y promulgación oficial del mismo.

(70) Alusión explícita a la petición formulada por sus nuevos súbditos del reino de Murcia, a raiz sobre todo de la conquista de la capital ( 19 mayo 1296) de concederles un Nuevo Fuero, que sustituyera al Fuero Real castellano, por el que estaban siendo gobernados desde Alfonso $X$ el Sabio hasta la fecha.

Jaime Il accedió complaciente a tal petición, ordenando ya a principios de julio del mismo año su laboriosa compilación a los tres jurisperitos antes mencionados, que lo llevaron a término feliz en un tiempo récord, menos de cuatro meses, pudiendo ser promulgado el 25 de octubre de aquel mismo año 1296.

(71) Nueva alusión a la obra recopiladora de los tres jurisconsultos citados, que compilaron en un volumen de cuatro libros el Nuevo Fuero del Reino de Murcia, con idéntica división al Fuero Real alfonsí, vigente hasta la fecha, aclarando puntos que en éste se hallaban dudosos o menos explícitos y complementando la legislación foral, rellenando o suprimiendo las lagunas existentes.

Sin embargo es preciso anotar que hasta la promulgación del Nuevo Fuero murciano (25 octubre 1296) se mantuvo en pleno vigor el Fuero Real castellano, por disposición expresa de Jaime II de Aragón. Pero eso sí, a partir de dicha fecha, la voluntad del monarca era contundente, que en adelante el Nuevo Fuero de Murcia habría de ser el único por el que se gobernaran en exclusiva todos los súbditos del reino murciano.

(72) Mención del jurisperito Juan de Meeya, uno de los compiladores del Nuevo Fuero de Murcia, interviniente en la redacción de esta carta real en condición de convalidador de la misma. 
(73) Permítaseme expresar aquí mi agradecimiento más cordial al Dr. Jordi Colomina, profesor de Filología Catalana, en esta Universidad de Alicante, por la correcta puntuación catalano-valenciana del texto primitivo. 